\title{
Prey size spectrum and bioenergetics of the mixotrophic dinoflagellate Karlodinium armiger
}

\author{
Terje Berge $^{1,2, *}$, Per Juel Hansen ${ }^{1}, \varnothing_{j}$ vind Moestrup ${ }^{2}$ \\ ${ }^{1}$ Marine Biological Laboratory, Aquatic Biology Department of Biology, University of Copenhagen, Strandpromenaden 5, \\ 3000 Helsingør, Denmark \\ ${ }^{2}$ Phycology Laboratory, Aquatic Biology Department of Biology, University of Copenhagen, Øster Farimagsgade 2D, \\ 1353 Copenhagen K, Denmark
}

\begin{abstract}
We studied the functional and numerical response and prey size spectrum in the tubefeeding dinoflagellate Karlodinium armiger. Growth rates were very low when no food was supplied (0.01 to $0.06 \mathrm{~d}^{-1}$ ). When $K$. armiger was fed the dinoflagellate Heterocapsa triquetra and the cryptophyte Rhodomonas salina, maximum growth rates $(\mu)$ were 0.48 and $0.55 \mathrm{~d}^{-1}$ and maximum ingestion rates were 215 and $597 \mathrm{pg} \mathrm{C}$ cell $^{-1} \mathrm{~d}^{-1}$, respectively. Much lower prey concentrations were required to saturate growth rates compared to the saturation of ingestion rates. The optimal prey size, in terms of ingestion rates, was $\sim 13 \mu \mathrm{m}$, which is close to the size of the predator. Smaller prey $(<8 \mu \mathrm{m})$ were

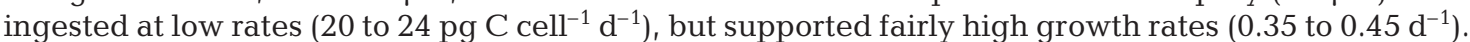
No upper prey size limit for ingestion was found. Maximum growth rates at food saturation depended more on prey taxa (cryptophytes) than on prey size. $K$. armiger's large range of prey types, wide prey size spectrum and nutritional flexibility seem to make it a significant competitor in marine plankton.
\end{abstract}

KEY WORDS: Mixotrophy $\cdot$ Bioenergetics $\cdot$ Prey selection $\cdot$ Peduncle $\cdot$ Karlodinium

\section{INTRODUCTION}

Dinoflagellates are important producers and consumers of organic material in the marine environment, and several species form blooms that disrupt planktonic ecosystems and kill fish and other fauna (Turner \& Tester 1997). Enhanced growth rates of photosynthetic dinoflagellates supplied with dissolved organic compounds (Gaines \& Elbrächter 1987) or particulate prey (Skovgaard 1996, Stoecker 1998) appear to be common for several bloom-forming species (e.g. Jeong et al. 2005a). The number of dinoflagellate species known to be mixotrophic has increased rapidly during recent years and is now $\sim 50$. In this paper, mixotrophy is used in the restricted sense: that photosynthesis and phagotrophic uptake of particulate prey take place in the organism simultaneously.

Some mixotrophic dinoflagellates show an obligate dependence on light (Stoecker et al. 1997) or food uptake (Skovgaard 2000), while others can grow almost equally well as phototrophs or heterotrophs, and are thus facultative mixotrophs (Skovgaard 1996). The extent to which phototrophy and heterotrophy are employed and the role of food uptake varies considerably, not only between different mixotrophic species but also within species subjected to different environmental parameters (Jones 1994, Stoecker 1998). In species with chloroplasts of their own, food uptake serves as a mean of obtaining organic carbon for heterotrophic metabolism and/or nutrients for phototrophic growth, and is regulated by light intensity and/or nutrient concentrations (Skovgaard 1996, Stoecker et al. 1997, Smalley et al. 2003). Alternatively, food is ingested to obtain essential micronutrients and/or growth factors (Li et al. 1999, Skovgaard 2000). Some mixotrophic species lack chloroplasts of their own and are largely heterotrophs, but they can either utilize functional chloroplasts derived from cryptophyte prey (Skovgaard 1998) or they harbor photosynthetic endosymbionts (Hansen et al. 2004). 
Protists belonging to the nano- or microplankton fractions are the most common prey items for dinoflagellates (Hansen 1998). In some cases, phagotrophic dinoflagellates show a high degree of prey specificity (Skovgaard 1996, 2000), but omnivorous forms which ingest any prey they can handle are also common (Hansen \& Calado 1999). The lower prey size limit for ingestion of prey particles is set by the predator's ability to detect and handle the prey, and is about 2 to $3 \mu \mathrm{m}$ (Calado et al. 1998, Hansen \& Calado 1999). A few studies have suggested that single bacterial cells may serve as an important food source for dinoflagellates (Porter 1988, Nygaard \& Tobiesen 1993, Jeong et al. 2005b), but these results have been questioned (Hansen 1998).

Phagotrophic dinoflagellates employ 3 main types of food uptake mechanisms: (1) direct engulfment, (2) tube feeding and (3) pallium feeding (Hansen \& Calado 1999). The feeding mechanism determines the kind of food that can be ingested. Direct engulfers and pallium feeders are restricted to food particles up to the volume capacity of the cell (Hansen \& Calado 1999). However, both direct engulfers and pallium feeders are able to ingest prey types several times larger than themselves (Jacobson \& Anderson 1986, Skovgaard 1996), and prey size spectra show that the optimal prey size corresponds roughly to the size of the predator itself (Hansen 1992, Naustvoll 2000a,b). Tube feeders suck out the contents of their prey into food vacuoles by using a feeding tube. In the literature, no prey size spectra are available for tube feeders, but several researchers have stressed that they do not have an upper size limit for ingestion, and there are reports of ingestion of rotifer and copepod eggs and even metazoans and tissues of fish (e.g. Hansen \& Calado 1999).

The recently established genus of small naked dinoflagellates Karlodinium comprises 4 described species: $K$. vitiligo, $K$. veneficum, $K$. australe and $K$. armiger (De Salas et al. 2005, Bergholtz et al. 2006). K. vitiligo has only been reported once and its identity is uncertain. The other 3 species are mixotrophic and potentially toxic (De Salas et al. 2005, Bergholtz et al. 2006, Berge et al. 2008, this issue). Monospecific blooms have occurred in protected embayments and lagoons in Europe, USA and Australia and have killed huge amounts of caged fish, mussels and other fauna (Deeds et al. 2002, Bergholtz et al. 2006).

The ecology of Karlodinium veneficum has been studied in both the field and laboratory (Li et al. 1999, $2000 a, b)$. Food uptake both serves as a source of carbon (Adolf et al. 2006) and of nutrients and/or growth factors that stimulate photosynthesis (Li et al. 1999). Both $K$. veneficum and $K$. armiger are obligate phototrophs, which are unable to grow without light (Li et al. 1999, Berge et al. 2008). Nevertheless, there appear to be some differences in their trophic strategies. Firstly, $K$. armiger ingests prey in the dark, which has not been observed in $K$. veneficum (Li et al. 1999, 2000a). Growth rates increase from $<0.1 \mathrm{~d}^{-1}$ without food to $\sim 0.6 \mathrm{~d}^{-1}$ when $K$. armiger is fed algal prey (Berge et al. 2008). In $K$. veneficum growth without food is faster $\left(\sim 0.4 \mathrm{~d}^{-1}\right)$, while light-saturated mixotrophic growth is similar in the 2 species when they are fed cryptophytes (0.6 to $0.7 \mathrm{~d}^{-1}$ ) (Li et al. 1999). In $K$. armiger food uptake seems to provide essential substances and/or growth factors, which $K$. veneficum can obtain in standard medium without food. To what extent $K$. armiger employs heterotrophic metabolism is unknown, but recent studies have shown that during mixotrophic growth in $K$. veneficum heterotrophy contributes the most (Adolf et al. 2006).

Although Karlodinium veneficum feeds on different protists (Li et al. 1999), previous studies of its ecology have focused on the feeding interactions with cryptophytes, and studies on prey specificity in $K$. veneficum are missing. Recently, $K$. armiger was shown to ingest several different kinds of prey, both heterotrophic and phototrophic, using an inconspicuous feeding tube (peduncle) which allows for ingestion of very large food particles (Berge et al. 2008). This indicates that mixotrophic members of Karlodinium are omnivorous tube feeders with a much larger range of suitable prey and wider prey size spectrum than previously recognized. The present study focuses on mixotrophy and prey selectivity in $K$. armiger when fed different algal prey. The specific aims were to (1) study the functional and numerical responses of $K$. armiger when fed 2 different prey species (a cryptophyte and a dinoflagellate) and (2) investigate the prey size spectrum when fed prey from different taxa in the size range 5.6 to $31 \mu \mathrm{m}$ (equivalent spherical diameter [ESD]).

\section{MATERIALS AND METHODS}

Cultures and experimental conditions. Algal cultures (Table 1) were obtained from the Scandinavian Culture Centre for Algae and Protozoa (www.sccap. bot.ku.dk). The clonal culture of Karlodinium armiger has been maintained without algal food since it was isolated in 2000. All stock cultures of $K$. armiger and prey species were grown in autoclaved L-medium ('L1' in Guillard \& Hargraves 1993), based on filtered seawater with a salinity of $32 \mathrm{PSU}$. Temperature was $15^{\circ} \mathrm{C}$ and irradiance was 130 to $200 \mu \mathrm{mol}$ photons $\mathrm{m}^{-2} \mathrm{~s}^{-1}$ in a 14:10 h light:dark cycle.

Growth and grazing experiments were conducted in glass vials mounted vertically on a plate submerged in a water-cooled $\left(15 \pm 0.3^{\circ} \mathrm{C}\right)$ plankton wheel incubator 
Table 1. Studied species, cell size and strain number. ESD = equivalent spherical diameter

\begin{tabular}{|c|c|c|c|}
\hline Species & $\mathrm{ESD}(\mu \mathrm{m})$ & Biovolume $\left(\mu \mathrm{m}^{3}\right)$ & Strain no. \\
\hline \multicolumn{4}{|l|}{ Bacillariophyceae } \\
\hline Nitzschia navis-varingica & 18.2 & 3500 & K-0620 \\
\hline \multicolumn{4}{|l|}{ Cryptophyceae } \\
\hline Rhodomonas baltica & 10.7 & 690 & K-0332 \\
\hline Rhodomonas marina & 10.1 & 640 & K-0435 \\
\hline Rhodomonas salina & 9.0 & 400 & K-0294 \\
\hline Teleaulax amphioxeia & 7.3 & 220 & K-0434 \\
\hline \multicolumn{4}{|l|}{ Dinophyceae } \\
\hline Karlodinium armiger & 13.1 to 16.7 & 1300 to 2700 & K-0668 \\
\hline Gyrodinium instriatum & 31.2 & 17980 & K-0273 \\
\hline Heterocapsa triquetra & 13.3 & 1350 & K-0447 \\
\hline Heterocapsa rotundata & 6.3 & 140 & K-0483 \\
\hline \multicolumn{4}{|l|}{ Prasinophyceae } \\
\hline Pyramimonas propulsa & 10.7 & 700 & K-0293 \\
\hline Pyramimonas orientalis & 5.6 & 100 & K-0003 \\
\hline \multicolumn{4}{|l|}{ Raphidophyceae } \\
\hline Heterosigma akashiwo & 12.0 & 990 & K-0541 \\
\hline \multicolumn{4}{|l|}{ Prymnesiophyceae } \\
\hline Prymnesium nemamethecum & 6.4 & 150 & K-0394 \\
\hline
\end{tabular}

(1 rpm). The rotating glass vials were carefully filled to maximum capacity and topped with a small piece of plastic laboratory film (parafilm) beneath the cap. This prevented formation of bubbles, which have a negative effect on the growth of Karlodinium armiger (T. Berge unpubl. data). Light was provided vertically from cool-white fluorescent tubes in a 14:10 h light: dark cycle and an irradiance of $180 \mu \mathrm{mol}$ photons $\mathrm{m}^{-2} \mathrm{~s}^{-1}$ during all experiments. Irradiance was measured with a spherical underwater sensor (Li185B, Li-Cor). Salinity was 32 PSU. Algal cells were kept in exponential growth phase under experimental conditions (light, rotation) for at least $4 \mathrm{~d}$ prior to incubation. All treatments containing $K$. armiger and prey cells, prey control cultures and predator controls were conducted in triplicate.

Recent studies have shown that phytoplankton cultures grown in standard media (e.g. f/2 and L) are often limited by high $\mathrm{pH}$ and not by the lack of nutrients (Schmidt \& Hansen 2001, Møgelhøj et al. 2006). Thus, when conducting feeding experiments on mixotrophic phytoplankton, it is essential to keep track of $\mathrm{pH}$ and to know the upper $\mathrm{pH}$ limits for growth of both predator and prey. Failure to do so may result in wrong conclusions. Growth of Karlodinium armiger is affected when $\mathrm{pH}>8.8$, and $\mathrm{pH}>9$ kills it (T. Berge unpubl. data). Care was therefore taken to ensure that $\mathrm{pH}$ never exceeded 8.6 in our experiments. This value is also below the high $\mathrm{pH}$ tolerance limit of all prey species used in the present study ( $T$. Berge unpubl. data). Adjustments of $\mathrm{pH}$ in the fresh medium were made by adding drops of $1 \mathrm{~N} \mathrm{HCl}$ and $1 \mathrm{~N} \mathrm{NaOH}$. At every sampling occasion, $\mathrm{pH}$ was measured before samples were withdrawn using a 2point calibration $\mathrm{pH}$ meter (pHM83, Radiometer).

Cell concentrations were determined by counting at least 300 Lugol's-fixed cells in a Sedgwick rafter counting chamber, using a 10× objective on a compound microscope. At low cell concentrations $\left(<300\right.$ cells $\left.\mathrm{ml}^{-1}\right)$, all cells in the chamber $(\sim 1 \mathrm{ml})$, or all cells in a $2 \mathrm{ml}$ settling chamber, were counted using an inverted microscope. The biovolume of algal cells was determined by measuring the width and length of the first 20 to 50 cells encountered, using an ocular micrometer and an inverted microscope (40× objective). The biovolume was estimated using simple geometric shapes, and the ESD was estimated by the equation: $\mathrm{ESD}=$ (biovolume / 0.523) ${ }^{0.33}$. For comparisons across diverse prey taxa and prey sizes, the cellular carbon content (pg C cell ${ }^{-1}$ ) was estimated from the relationship between carbon content and biovolume for protists by Menden-Deuer \& Lessard (2000).

Bioenergetics. Functional and numerical responses: An experiment was set up to study the functional and numerical response of Karlodinium armiger when fed Rhodomonas salina (Cryptophyceae, ESD $9 \mu \mathrm{m}$ ) and Heterocapsa triquetra (Dinophyceae, ESD $13 \mu \mathrm{m}$ ). In addition, phototrophic growth of $K$. armiger was studied without prey cells. The predator cells were acclimatized to prey species and prey concentrations for $10 \mathrm{~d}$ prior to inoculation. The acclimation period was conducted by mixing predator cells from a stock culture which had been grown phototrophically for an extended period (several months) with exponentially growing $R$. salina and $H$. triquetra cells. Prey concentrations ranged from 100 to 30000 cells $\mathrm{ml}^{-1}$. Unialgal prey control cultures were set up under similar conditions. During the acclimation period, $\mathrm{pH}$ and cell concentrations were measured every 1 to $4 \mathrm{~d}$ and adjusted by adding exponentially growing prey cells and fresh L-medium of $\mathrm{pH} 7.8$. The $\mathrm{pH}$ did not exceed 8.5 during the acclimation (see section 'Cultures and experimental conditions').

The experiment was initiated by incubating the mixotrophically acclimated Karlodinium armiger cells with prey cells at prey concentrations ranging from 100 to 35000 cells ml-1. An unfed $K$. armiger culture was set up as control (phototrophic growth). To calculate ingestion rates, a prey control culture was set up in parallel at each prey concentration (see 'Calculations'). After inoculation, the cells were allowed to grow for $3 \mathrm{~d}$ prior to daily sampling for 5 to $10 \mathrm{~d}$. Fresh 
L-medium with a $\mathrm{pH} 7.5$ to 7.8 replaced the sample volumes (5 to $10 \mathrm{ml}$ corresponding to 20 to $40 \%$ of total volume), resulting in semi-continuous cultures. During the assay, cell dimensions, cell concentrations and $\mathrm{pH}$ were measured as described in the section 'Cultures and experimental conditions'.

Calculations: Exponential growth rate of Karlodinium armiger $\left(\mu_{\mathrm{y}}, \mathrm{d}^{-1}\right)$ was estimated in steps of $24 \mathrm{~h}$ due to the daily dilutions and averaged over at least 3 points on a linear portion of a semi-log plot of concentration as a function of time using:

$$
\mu_{\mathrm{y}}=\ln \left(N_{1}-N_{0}\right) / t
$$

where $N_{1}-N_{0}$ is the change in concentration of Karlodinium armiger cells during the time interval $t$. The biomass production rate of $K$. armiger (pg C cell-1 $\mathrm{d}^{-1}$ ) was estimated as:

\section{Biomass production $=\mu_{\mathrm{y}} \times \mathrm{C}_{\mathrm{y}}$}

where $\mathrm{C}_{\mathrm{y}}$ is the biomass of predator cells (pg C cell ${ }^{-1}$ ).

Ingestion rate $U$ (prey cells predator ${ }^{-1} \mathrm{~d}^{-1}$ ) was estimated by comparing over $24 \mathrm{~h}$ periods the change in prey concentration in vials containing predator cells with the change in prey control concentrations without predator cells (e.g. Jakobsen \& Hansen 1997). This method assumes that the prey grows exponentially at the same rate as in the predator-free prey control vials. This was fulfilled by (1) using full-strength L-medium, (2) enrichment with fresh medium during sampling, and (3) controlling the development of $\mathrm{pH}$ (see 'Cultures and experimental conditions'). The 2 following equations were used in an iterative model (steps of $0.01 \mathrm{~h}$ ) to calculate ingestion rate $\mathrm{U}$, which is independent of prey concentration:

$$
\begin{gathered}
\mathrm{d} x / \mathrm{d} t=\mu_{\mathrm{x}} x-\mathrm{U} y \\
\mathrm{~d} y / \mathrm{d} t=\mu_{\mathrm{y}} y
\end{gathered}
$$

The prey $x$ is ingested by the predator $y$ at the predator-induced prey mortality $\mathrm{U} y$. Clearance $\mathrm{F}$ (ml cell ${ }^{-1}$ $\mathrm{h}^{-1}$ ) was calculated as:

$$
\mathrm{F}=\mathrm{U}_{\mathrm{x}} / \mathrm{x}
$$

where $\mathrm{x}$ is the prey concentration (cells $\mathrm{ml}^{-1}$ ). For statistical analysis of pairwise differences between prey species, ANOVA 1-factor analyses were used to test for differences between means. Mean values were averaged over at least 3 points on linear parts of semi-log plots of concentration as function of time. When comparing groups (e.g. cryptophytes vs. other taxa, smaller vs. larger prey), the data were grouped. To determine the prey concentrations that saturated ingestion, the data for ingestion when Karlodinium armiger was fed the dinoflagellate Heterocapsa triquetra and the cryptophyte Rhodomonas salina were fitted to the Michaelis-Menten equation.
Prey selectivity. Prey screening: In this - the first of 2 sets of experiments conducted to study prey selctivity - we investigated the initial ( 0 to $23 \mathrm{~d}$ ) development in cell concentrations when Karlodinium armiger was fed 11 different prey species, representing 6 algal classes (Table 1). Predator and prey cells were mixed in an initial predator:prey cell concentration ratio of 1:5. When fed Rhodomonas marina, initial predator: prey cell concentration ratio was 1:10. Prey control cultures were set up at the same initial prey concentrations as in the mixed cultures. For comparison, K. armiger was grown without prey cells. Samples for enumeration of cell concentrations were taken every second day for up to $23 \mathrm{~d}$. When fed $R$. marina and Pyramimonas propulsa, samples were taken every day. Dilution rate corresponded to a growth rate of $0.14 \mathrm{~d}^{-1}$. If the prey was depleted during the experiment, additional prey cells were added.

Prey size spectrum: We compared ingestion and growth rates of Karlodinium armiger fed different prey species at saturating food concentrations. The predator cells were acclimatized to prey species and high prey concentrations, as described in the section 'Functional and numerical responses'. Three treatments with different prey concentrations were set up for 5 different prey species. Prey ranged in size (ESD) from 5.6 to $31.4 \mu \mathrm{m}$ and represented 4 different algal classes. Prey species were Rhodomonas baltica (Cryptophyceae), Heterocapsa rotundata (Dinophyceae), Gyrodinium instriatum (Dinophyceae), Heterosigma akashiwo (Raphidophyceae) and Pyramimonas orientalis (Prasinophyceae). For comparison, the results derived from the functional and numerical responses of $K$. armiger were included when fed $R$. salina and Heterocapsa triquetra at food-saturated conditions.

\section{RESULTS}

\section{Bioenergetics}

Ingestion rate increased as a function of prey concentration when Karlodinium armiger was fed both Heterocapsa triquetra and Rhodomonas salina. The food saturation was obtained at the same prey biomass, $\sim 0.85 \times 10^{6} \mathrm{pg} \mathrm{C} \mathrm{ml}{ }^{-1}$ when fed both species. However, maximum ingestion rates were significantly lower ( 64\% lower) when $K$. armiger was fed $H$. triquetra compared to $R$. salina ( $<<0.01$ ) (Fig. 1A,B).

In unfed cultures (light intensity $=180 \mu \mathrm{mol}$ photons $\mathrm{m}^{-2} \mathrm{~s}^{-1}$ ), the growth rate of Karlodinium armiger was low $\left(0.06 \mathrm{~d}^{-1}\right)$. When fed, growth rate increased considerably and leveled off at a maximum growth rate of $0.52 \mathrm{~d}^{-1}$ (Rhodomonas salina) and $0.46 \mathrm{~d}^{-1}$ (Hetero- 

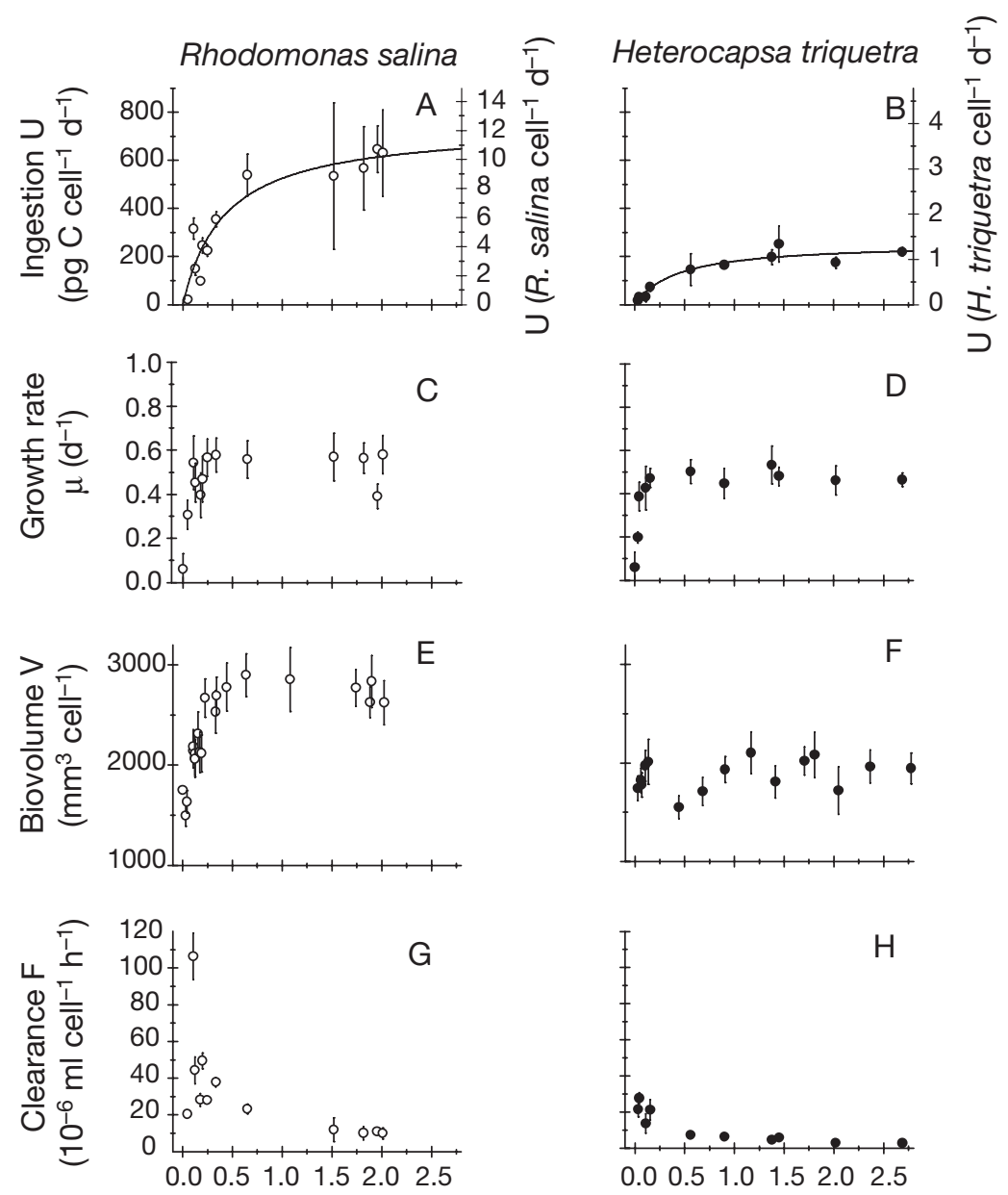

$\left(10^{6} \mathrm{pg} \mathrm{C} \mathrm{ml}^{-1}\right)$

051015202530354045

$\left(10^{3}\right.$ R. salina $\left.\mathrm{ml}^{-1}\right)$ $\begin{array}{llllllllll}0 & 2 & 4 & 6 & 8 & 10 & 12 & 14\end{array}$

$\left(10^{3} \mathrm{H}\right.$. triquetra $\left.\mathrm{ml}^{-1}\right)$

Prey concentration

Fig. 1. Karlodinium armiger. Bioenergetics when fed Rhodomonas salina (O) and Heterocapsa triquetra $(\bullet)$. (A,B) Ingestion rate $(\mathrm{U}),(\mathrm{C}, \mathrm{D})$ growth rate $(\mu),(\mathrm{E}, \mathrm{F})$ predator biovolume $(\mathrm{V})$ and $(\mathrm{G}, \mathrm{H})$ clearance $(\mathrm{F})$ as functions of prey concentration. Data are mean $\pm 1 \mathrm{SE}$

capsa triquetra) (Fig. 1C,D). These growth rates at prey saturation were, however, not statistically different $(\mathrm{p}=0.276)$. The biovolume $\left(\mu \mathrm{m}^{3} \mathrm{cell}^{-1}\right)$ of $K$. armiger increased with prey concentration, and reached a

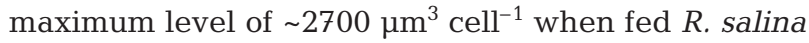
(Fig. 1E). When fed $H$. triquetra, the biovolume of $K$. armiger was smaller $\left(\sim 2000 \mu^{3}\right.$ cell $\left.^{-1}\right)(\mathrm{p}<0.001)$ (Fig. 1F). Due to the larger biovolume of predator cells fed $R$. salina, the cryptophyte supported significantly higher $(\mathrm{p}<0.001)$ mean biomass production rate (203 pg C cell ${ }^{-1} \mathrm{~d}^{-1}$ ) than $H$. triquetra (129 pg C cell ${ }^{-1}$ $\left.\mathrm{d}^{-1}\right)$, although growth rates were statistically similar.
Clearance decreased asymptotically with prey concentration, reaching significantly different $(\mathrm{p}<0.001)$ levels at saturating prey concentrations when fed the 2 prey species (Fig. 1G,H). At high prey concentrations $\left(>1 \times 10^{6} \mathrm{pg} \mathrm{C} \mathrm{ml}^{-1}\right)$, Heterocapsa triquetra was cleared from the water at a mean rate of $5 \times 10^{-6} \mathrm{ml}$ cell $^{-1} \mathrm{~h}^{-1}$, compared to $11 \times 10^{-6} \mathrm{ml}$ cell $^{-1} \mathrm{~h}^{-1}$ when fed Rhodomonas salina (Fig. 1G,H). At prey concentrations $<0.2 \times 10^{6} \mathrm{pg} \mathrm{C} \mathrm{ml}^{-1}$, the mean clearance was $56 \times 10^{-6} \mathrm{ml} \mathrm{cell}^{-1} \mathrm{~h}^{-1}$ of the cryptophyte, compared to $20 \times 10^{-6} \mathrm{ml} \mathrm{cell}^{-1} \mathrm{~h}^{-1}$ of the dinoflagellate $(\mathrm{p}<0.01)$.

\section{Prey selectivity}

\section{Screening and prey species}

The first set of experiments on prey selectivity aimed to study the initial (20 to $23 \mathrm{~d}$ ) development of cell concentrations in cultures fed 11 different prey species, and in prey and predator monocultures (Fig. 2). Without food, the concentration of Karlodinium armiger cells declined throughout the experimental period, but the rate of decline was lower than the dilution rate $\left(0.14 \mathrm{~d}^{-1}\right)$. The mean phototrophic growth rate during this period was $0.01 \mathrm{~d}^{-1}$. However, in all cultures containing prey other than the diatom Nitzschia navis-varingica, cell concentrations of $K$. armiger increased with time and the prey populations were affected by grazing. $K$. armiger thus increased its growth by feeding on all algal prey species offered except the diatom (Fig. 2). Maximum growth rates supported by the different prey species were in the range 0.20 to $0.65 \mathrm{~d}^{-1}$ (derived from curves in Fig. 2). In general, the effect of grazing was highest on the prey populations of the cryptophytes Rhodomonas baltica and $R$. marina and on the dinoflagellate Heterocapsa triquetra. These 3 prey species were depleted after 4, 8 and 6 d, respectively, and supported the highest mixotrophic growth. When prey populations were depleted, growth of $K$. armiger resumed levels similar to that in the unfed culture (see e.g. ' $R$. marina' in Fig. 2). All prey species $<8 \mu \mathrm{m}$ (ESD) survived at prey concentrations ranging from 100 to 300 cells $\mathrm{ml}^{-1}$ during the experimental period (20 to $23 \mathrm{~d}$ ). 

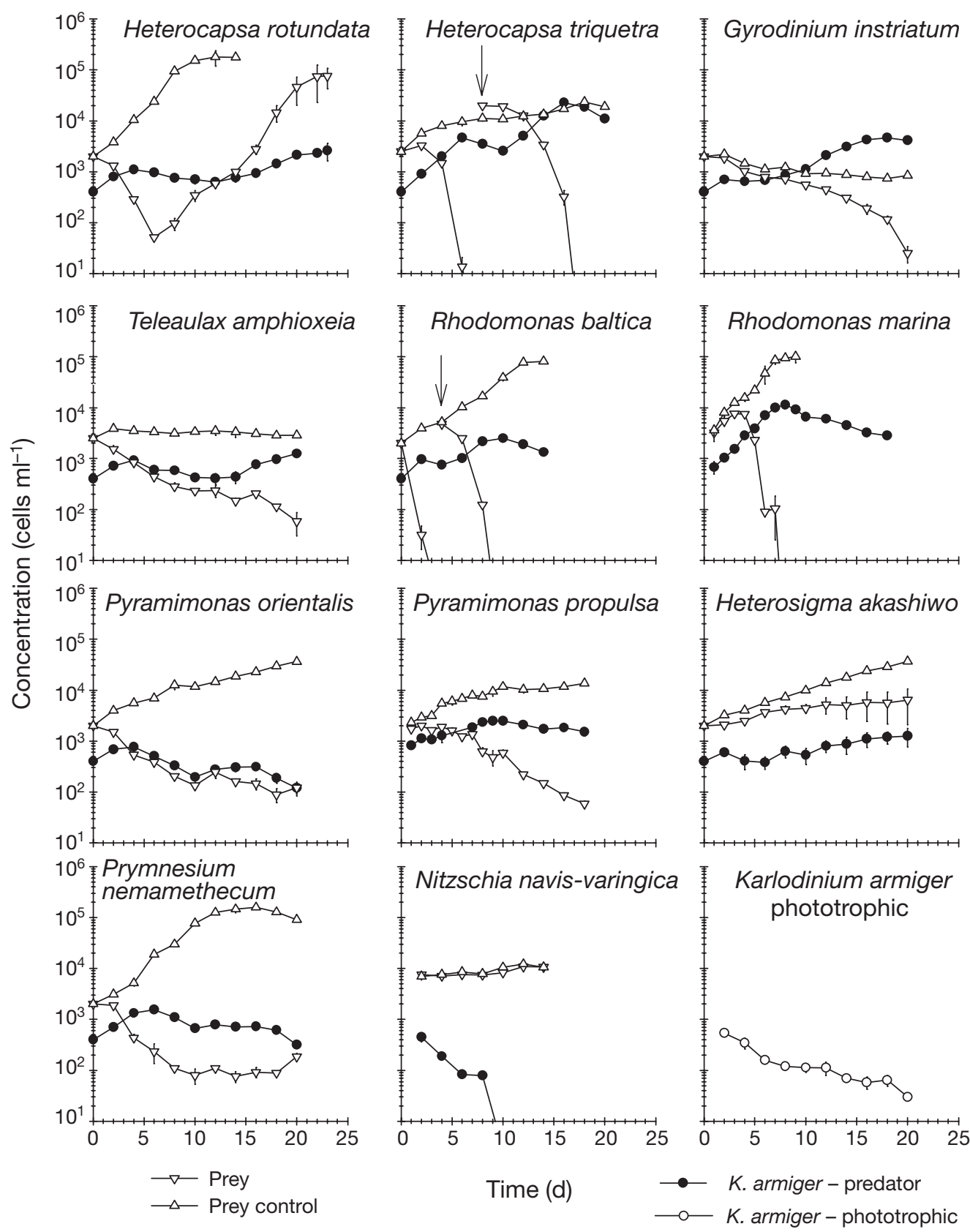

Fig. 2. Karlodinium armiger. Prey screening experiment. Growth curves (cell concentration as a function of time) of predator, prey and prey control cultures. Dilution rate corresponded to a growth rate of $0.14 \mathrm{~d}^{-1}$. Arrows indicate time of addition of new prey cells. Data are mean $\pm 1 \mathrm{SE}$

\section{Prey size spectrum}

The second set of experiments on prey selectivity compared ingestion and growth rates of mixotrophically acclimated Karlodinium armiger cells fed 5 different prey species in food-saturated cultures (Fig. 3). For comparison, the results obtained under prey-saturated conditions when $K$. armiger was fed Heterocapsa tri- quetra and Rhodomonas salina (see 'Bioenergetics') were included in Fig. 3 and Table 2. These 7 species offered as prey supported growth rates that were significantly faster $(p<0.001)$ than the growth rates in phototrophic cultures $\left(0.01\right.$ to $\left.0.06 \mathrm{~d}^{-1}\right)$. Mixotrophic growth rates were in the range 0.35 to $0.65 \mathrm{~d}^{-1}$, while biomass production was in the range 77 to $214 \mathrm{pg} \mathrm{C}$ cell $^{-1} \mathrm{~d}^{-1}$ (Fig. 3A). The fastest growth rates were sup- 


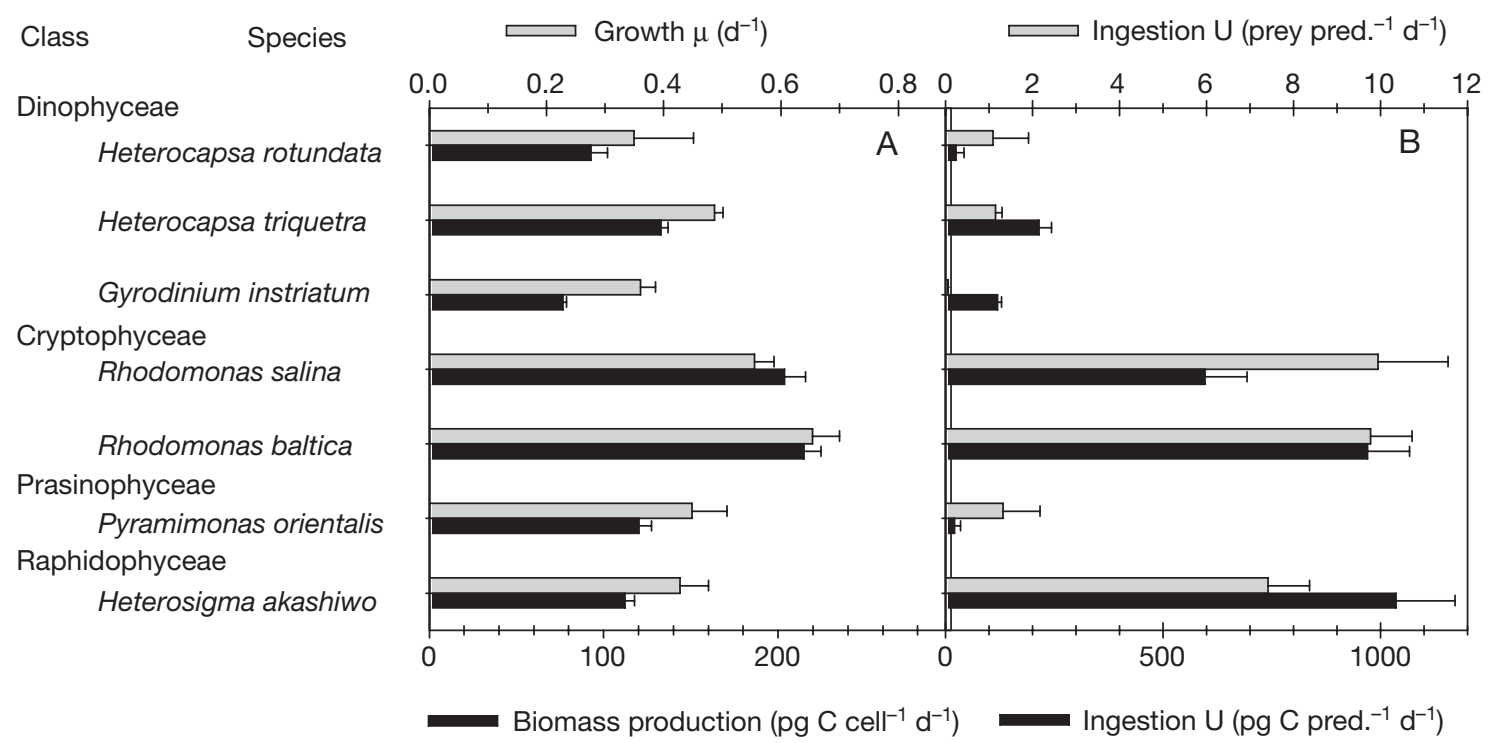

Fig. 3. Karlodinium armiger. Prey spectrum experiment. (A) Growth and biomass production rates, and (B) ingestion rates (U) at prey-saturated food concentrations when fed different prey species. Data are mean $\pm 1 \mathrm{SE}$

ported by cryptophytes ( 0.56 to $\left.0.65 \mathrm{~d}^{-1}\right)$, which were ingested at high rates (600 to $944 \mathrm{pg} \mathrm{C} \mathrm{cell}^{-1} \mathrm{~d}^{-1}$ ) (Fig. 3A,B). Biomass production rates were significantly higher when fed the 2 cryptophytes, compared to all the other prey species ( $\mathrm{p}<0.001)$ (Fig. 3A). In terms of carbon, Heterocapsa rotundata and Pyramimonas orientalis (both $<7 \mu \mathrm{m}$ ) were ingested at significantly lower rates (20 to $24 \mathrm{pg} \mathrm{C}$ cell ${ }^{-1} \mathrm{~d}^{-1}$ ) than larger (9 to $31 \mu \mathrm{m})$ prey (142 to $1024 \mathrm{pg} \mathrm{C}$ cell $\left.^{-1} \mathrm{~d}^{-1}\right)$ ( $\mathrm{p}<$ 0.001) (Fig. 3B). The raphidophyte Heterosigma akashiwo was grazed at a high ingestion rate similar to $R$. baltica $(\mathrm{p}=0.73)$, but the growth and biomass production rates were significantly lower $\left(0.43 \mathrm{~d}^{-1}\right)(\mathrm{p}<$ 0.05) (Fig. 3). The largest species, the dinoflagellate Gyrodinium instriatum, was grazed at higher ( $\mathrm{p}<$ 0.001) ingestion rates (142 pg C cell ${ }^{-1} \mathrm{~d}^{-1}$ ) compared to the 2 small species $H$. rotundata and $P$. orientalis (20 to $24 \mathrm{pg} \mathrm{C}$ cell $\mathrm{d}^{-1} \mathrm{~d}^{-1}$ ), but supported statistically similar growth rates $(p=0.44)$ (Fig. 3$)$. Nevertheless, due to the lower biovolume of $K$. armiger fed $G$. instriatum, the biomass production rate was lower when fed this species than when fed $H$. rotundata and $P$. orientalis $(\mathrm{p}<0.05)$ (Fig. 3A).

The growth and grazing parameters of Karlodinium armiger at food saturation are summarized in Table 2. When fed excess food, the biovolume of the predator depended on the prey species. The largest predator biovolume was supported by cryptophyte prey (2449 to

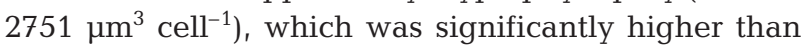
the biovolume when fed all the other species $(\mathrm{p}<$ 0.001). Gyrodinium instriatum supported the smallest

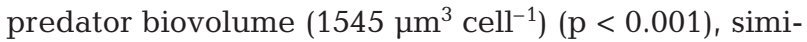

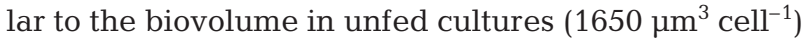
$(\mathrm{p}=0.41)$. The 4 other prey species, Pyramimonas orientalis $(\mathrm{ESD}=5.6)$, Heterocapsa rotundata $(\mathrm{ESD}=6.3)$, Heterosigma akashiwo $(\mathrm{ESD}=12.1)$ and Heterocapsa triquetra $(\mathrm{ESD}=13.4$ ), supported predator biovolumes ranging from 1925 to $2009 \mathrm{\mu m}^{3} \mathrm{cell}^{-1}$ (Table 2).

Table 2. Karlodinium armiger fed 7 different prey species in food-saturated cultures. SE in parentheses

\begin{tabular}{|c|c|c|c|c|c|c|}
\hline Prey species & $\begin{array}{l}\text { Inges } \\
\text { prey cell }\end{array}$ & $\begin{array}{l}\text { tion } \mathrm{U}-\overline{\operatorname{pg~}^{\mathrm{C}} \mathrm{cell}^{-1} \mathrm{~d}^{-1}}\end{array}$ & $\begin{array}{l}\text { Growth rate } \mu \\
\mathrm{d}^{-1}\end{array}$ & 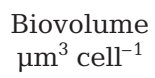 & $\begin{array}{l}\text { Biomass production } \\
\text { pg C cell }{ }^{-1} \mathrm{~d}^{-1}\end{array}$ & $\begin{array}{c}\text { Clearance F } \\
10^{-6} \mathrm{ml} \mathrm{cell}^{-1} \mathrm{~h}^{-1}\end{array}$ \\
\hline Pyramimonas orientalis & $1.3(0.9)$ & $20(14)$ & $0.45(0.06)$ & $1973(87)$ & $120(7.2)$ & $4.9(1.2)$ \\
\hline Heterocapsa rotundata & $1.1(0.8)$ & $24(18)$ & $0.35(0.10)$ & $1950(168)$ & $93(9.4)$ & $1.5(0.3)$ \\
\hline Rhodomonas salina & $9.9(1.6)$ & $597(97)$ & $0.55(0.03)$ & $2751(87)$ & $203(12.2)$ & $10.9(1.2)$ \\
\hline Rhodomonas baltica & $9.8(1.0)$ & $974(96)$ & $0.65(0.05)$ & 2449 (103) & $214(9.9)$ & $10.8(1.7)$ \\
\hline Heterosigma akashiwo & $7.4(1.0)$ & 1024 (135) & $0.43(0.05)$ & 1925 (119) & $112(5.5)$ & $19.6(3.1)$ \\
\hline Heterocapsa triquetra & $1.1(0.2)$ & $215(28)$ & $0.48(0.01)$ & 2009 (105) & $129(4.0)$ & $5.0(0.5)$ \\
\hline Gyrodinium instriatum & $0.1(0.01)$ & $142(10)$ & $0.36(0.03)$ & $1545(75)$ & $77(2.0)$ & $2.5(2.4)$ \\
\hline
\end{tabular}


The growth and grazing parameters of Karlodinium armiger at saturating prey concentrations were used to draw prey size spectra (Fig. 4). The ingestion rate increased with prey size up to an optimum prey size of $\sim 13 \mu \mathrm{m}$, which is close to the size of the predator itself (Fig. 4A). Prey species larger than the optimum prey

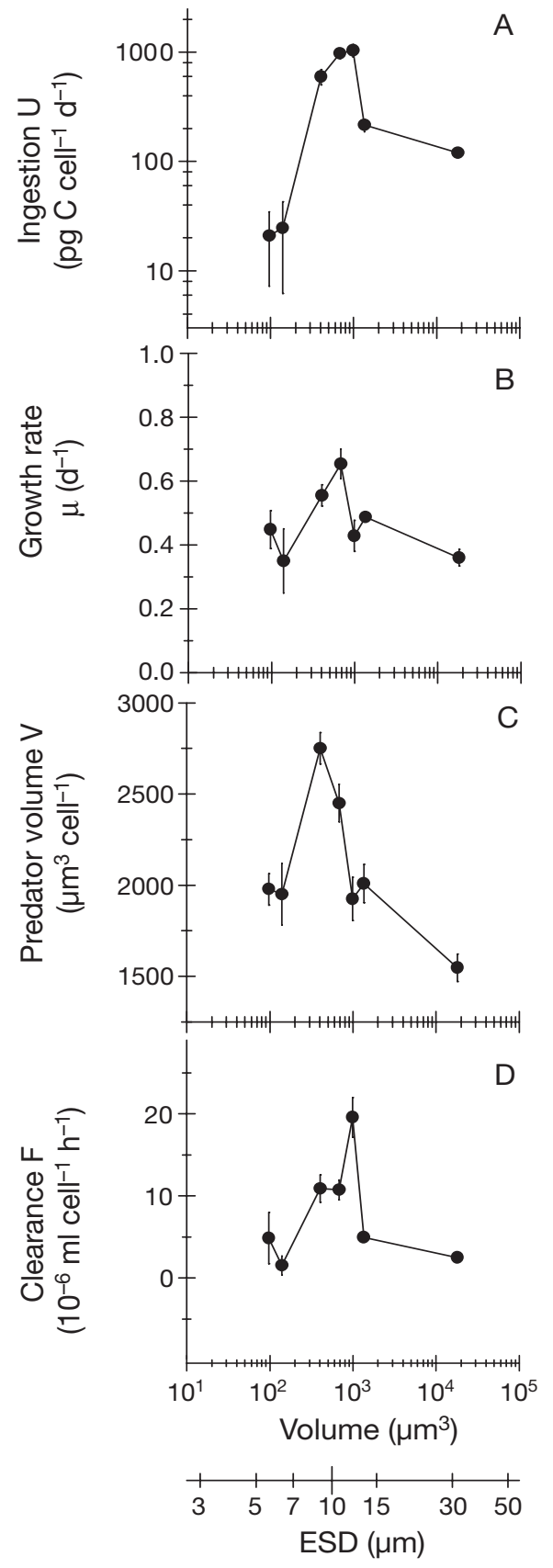

Prey size

Fig. 4. Karlodinium armiger. Prey size spectra. (A) Ingestion rate $(\mathrm{U}),(\mathrm{B})$ growth rate $(\mu),(\mathrm{C})$ predator biovolume $(\mathrm{V})$ and (D) clearance $(F)$ as functions of prey size. Data are mean $\pm 1 \mathrm{SE}$ size were ingested at higher rates than the 2 smallest species $(<7 \mu \mathrm{m})(\mathrm{p}<0.001)$. Growth rate (Fig. 4B) and predator biovolume (Fig. 4C) were less affected by prey size than ingestion rates, and more strongly correlated with prey species (see Fig. 3). Clearance at food saturation increased as a function of prey size up to the maximum at $\sim 13 \mu \mathrm{m}$ and declined at larger prey sizes (Fig. 4D).

\section{DISCUSSION}

\section{Bioenergetics and mixotrophy}

In this study, the growth rate of Karlodinium armiger in a standard growth medium in the light was slow (0.01 to $\left.0.06 \mathrm{~d}^{-1}\right)$ even at relatively high irradiances. When $K$. armiger was provided with prey cells under similar light conditions, the growth rates were enhanced, and the magnitude of increase depended on prey species and prey concentration (Figs. 1 \& 4). Our ingestion and growth rates compare well with results for $K$. veneficum fed similar prey at food-saturated prey concentration, and grown under similar nutrient and light levels $\left(\mathrm{U} \approx 7\right.$ Storeatula major cell $^{-1} \mathrm{~d}^{-1}, \mu \approx$ $0.7 \mathrm{~d}^{-1}, 20^{\circ} \mathrm{C}$ ) (Li et al. 1999). The grazing rates of these mixotrophs are comparable to grazing rates of purely heterotrophic dinoflagellates (Hansen et al. 1997), while their growth rates are lower. The lower growth rate is probably related to the cost of the photosynthetic apparatus, which may be up to $50 \%$ of the cell's energy requirement, compared to only $10 \%$ for the heterotrophic apparatus (Raven 1997, Stoecker 1998).

The growth rate of Karlodinium armiger saturated at low prey concentrations when it was fed Heterocapsa triquetra or Rhodomonas salina (Fig. 1). Nevertheless, ingestion rates continued to increase as function of prey concentration, without a corresponding increase in growth and biomass production rate (Fig. 1A-F). In purely heterotrophic protists, an increase in the ingestion rate results in a corresponding (linear) increase in growth, and a plot of growth as a function of ingestion displays a linear relationship (e.g. Hansen 1992, Jakobsen \& Hansen 1997). Results similar to ours have been reported from other studies of mixotrophic protists (e.g. Jakobsen et al. 2000, Smith \& Hansen 2007). Thus, at low food concentrations, feeding in $K$. armiger may stimulate photosynthesis by supplying the cells with essential nutrients or growth factors (Berge et al. 2008), while heterotrophy seems to dominate at high food concentrations. In $K$. veneficum, chlorophyll $a$ normalized photosynthetic performance increases in cultures fed with cryptophytes (Li et al. 1999), while heterotrophy dominates in food-saturated mixotrophic growth (Adolf et al. 2006). 


\section{Prey selection}

Karlodinium armiger was fed phototrophic protists in the size range 5.6 to $31.4 \mu \mathrm{m}$ (ESD). The largest prey species offered, Gyrodinium instriatum, which is 13 times the size of the predator in terms of biovolume, supported a moderate ingestion rate and increased growth rate. This finding supports the previous view that no upper prey size limit for ingestion exists in tube-feeding dinoflagellates (Gaines \& Elbrächter 1987, Hansen \& Calado 1999). The smallest species offered, Pyramimonas orientalis (ESD $5.6 \mu \mathrm{m}$ ) and Heterocapsa rotundata (ESD $6.3 \mu \mathrm{m})$, were ingested at low rates (Figs. $3 \& 4$ ), and small prey species were never depleted in mixed cultures (Fig. 2). A mechanical explanation may be that the encounter rate between randomly swimming cells increases as a function of particle size and swimming speed. In addition, small species may be more difficult to capture. Optimal prey size for food uptake in the present study was $\sim 13 \mu \mathrm{m}$, which is close to the size of the predator. This agrees with previous prey size selection studies in dinoflagellates (Hansen 1992, Naustvoll 2000a,b), and supports the recognition of the raptorial nature of phagotrophic dinoflagellates (Hansen 1992, Hansen \& Calado 1999). Nevertheless, $K$. armiger did not ingest and grow faster when fed the diatom species offered (ESD $18 \mu \mathrm{m})$, supporting the view that diatoms are less suitable food for this tube feeder (Berge et al. 2008).

When the predator ingested small amounts $(\sim 20 \mathrm{pg}$ C cell ${ }^{-1} \mathrm{~d}^{-1}$ ) of small prey, growth rates were 5 to 8 times higher ( 0.35 to $0.45 \mathrm{~d}^{-1}$ ) than growth without food $\left(0.06 \mathrm{~d}^{-1}\right)$. Small prey may therefore be useful for Karlodinium armiger by providing essential growth factors which are required for photosynthetic growth (Berge et al. 2008). In nature, K. armiger may therefore grow mostly phototrophically when the available food comprises predominantly small nanoplanktonic flagellates $(<7 \mu \mathrm{m})$. When larger prey types are present at high concentrations, growth on ingested organic carbon (heterotrophy) seems to become more important. This nutritional flexibility combined with a wide prey spectrum provides adaptive properties in environments with fluctuations in food composition and abundance.

There is generally good agreement between prey size spectra of heterotrophic dinoflagellates based on ingestion and growth (Hansen 1992, Jakobsen \& Hansen 1997). However, in the present mixotrophic dinoflagellate, growth rates varied less than ingestion rates as a function of prey size (Fig. 4). Maximum growth rate at prey saturation seemed to be more correlated with prey taxa (cryptophytes) than with prey size (Figs. 3 \& 4). This may be explained by differences in the effects of different prey types on photosynthesis, or on differences in the nutritional quality of the prey. When Karlodinium armiger was fed Heterocapsa akashiwo, about $1000 \mathrm{pg} \mathrm{C}$ cell $^{-1} \mathrm{~d}^{-1}$ was ingested while only about $100 \mathrm{pg} \mathrm{C}$ cell $^{-1} \mathrm{~d}^{-1}$ was produced (Table 2). This indicates very low growth efficiency $(<10 \%)$ of this prey, perhaps because of the production of toxins and/or mucus.

The biovolume of Heterocapsa triquetra $\left(1400 \mathrm{\mu m}^{3}\right.$ cell $\left.^{-1}\right)$ is closer to the biovolume of the predator (1300 to $2500 \mathrm{\mu m}^{3} \mathrm{cell}^{-1}$ ) than of the cryptophyte Rhodomonas baltica $\left(685 \mathrm{\mu m}^{3}\right)$, but the cryptophytes were ingested at higher rates in terms of biomass. This is in contrast to what is expected from present ideas on the optimum prey size of dinoflagellates (Jacobson \& Anderson 1986, Hansen 1992) and indicates that prey selection in Karlodinium armiger relates not only to prey size. Food capture in $K$. armiger involves a capture filament, and escape of captured prey from the filament is common (Berge et al. 2008). Escape mechanisms have been observed in several plankton protists (Jakobsen \& Hansen 1997, Tillmann 2004, Jakobsen et al. 2006). The theca of $H$. triquetra may limit the rate of food uptake, due to the need for the peduncle to pierce the cells (Berge et al. 2008). Moreover, dinoflagellates are known to display chemosensory behavior (Spero 1985, Calado \& Moestrup 1997), and swarming behavior with aggregation of several $K$. armiger cells on a single food item was reported to be frequent in cultures fed different kinds of prey (Berge et al. 2008). Differences in the chemical cues released by different prey organisms may affect attraction and thus selection of prey. Prey size affects the magnitude of these chemical gradients.

The prey size spectrum of this tube-feeding mixotroph seems to depend on the qualities (e.g. nutritional value, swimming properties, cell coverings) of the prey species provided. The optimum prey size might have been larger and/or wider if other prey types of more similar qualities had been offered as food. High feeding frequencies in mixed cultures of Karlodinium armiger and the raphidophyte Fibrocapsa japonica, which is $\sim 5$ times larger (biovolume) than the predator, support this hypothesis (T. Berge pers. obs.). Nevertheless, despite the fact that factors other than size seem to be significant in prey selection of $K$. armiger, grazing was highest on the largest species of cryptophyte used in the present study, and populations of small prey were never depleted (Fig. 2).

\section{Ecological implications}

The large range of prey sizes suitable as food for Karlodinium armiger and the lack of an upper prey size limit show this species to compete for food in the size 
range 7 to $8 \mu \mathrm{m}$ and above (Fig. 4). Heterotrophic protists in the size range 10 to $200 \mu \mathrm{m}$ probably represent the most important competitors for K. armiger in terms of food (Hansen et al. 1997). Maximum growth rates of these heterotrophs are generally higher than in $K$. armiger and of dinoflagellates in general (Raven 1997), which suggests that the former are competitively superior. However, the ability to combine phototrophy with heterotrophy at low food concentrations may explain why this mixotroph can compete successfully with its faster growing heterotrophic competitors. Moreover, $K$. armiger ingests both plastidic and non-plastidic prey (Berge et al. 2008), and the heterotrophic competitors may become prey and/or predators of $K$. armiger. Production of toxins may favor Karlodinium spp. in these interactions (Adolf et al. 2006, 2007). The ability to increase heterotrophy when food is abundant is advantageous, since high grazing rates reduce the abundance of heterotrophic competitors for food and autotrophic competitors for nutrients. In nutrientdepleted waters, mixotrophs may also obtain nutrients from food uptake and thereby out-compete purely autotrophic species. This is the case in $K$. veneficum (Li et al. 2000a), and acquisition of nutrients by phagotrophy has been found to play an important role in other bloom-forming mixotrophic dinoflagellates (Smalley et al. 2003).

The prey concentrations supporting maximum growth rates of Karlodinium armiger fed both the cryptophyte Rhodomona salina and the dinoflagellate Heterocapsa triquetra (i.e. approximately 20 to $50 \mu \mathrm{g}$ $\mathrm{Cl}^{-1}$ ) are in the range of phytoplankton concentrations found in marine waters. Values above this level are, however, often recorded (e.g. Li et al. 2000a,b). Although $K$. armiger depends on photosynthesis, it may exert significant grazing pressure on nano- and micro-phytoplankton of cell size $>8 \mu \mathrm{m}$ (ESD). Our results on clearance rates suggest that if $K$. armiger is present at concentrations of $\sim 400$ cells $\mathrm{ml}^{-1}$, it can remove about 10 to $100 \%$ of the cryptophyte (in the size range 9 to $11 \mu \mathrm{m}$ ) populations and 5 to $30 \%$ of the $H$. triquetra $(13.4 \mu \mathrm{m})$ populations per day, depending on prey concentration. In nature, $K$. armiger has been found to occur at bloom concentrations of 100 to 1000 cells ml $^{-1}$ (Garcés et al. 1999), indicating that it can remove other algal populations and become numerically dominating. The similar and closely related $K$. veneficum has been observed at concentrations up to 60000 cells ml $^{-1}$ (Deeds et al. 2002).

Diatoms primarily dominate in time and space where ecosystems experience new production. New production is associated with fronts and upwelling systems, and in temperate waters takes place during the early spring when light levels increase, inducing diatom spring blooms based on resuspended nutrients (Kiør- boe 1993). Under these circumstances, species such as Karlodinium armiger may be poor competitors, due to lack of suitable prey. Subsequently, when regenerated production dominates, based on remineralized nutrients in the euphotic zone of stratified water columns, the phytoplankton is more dominated by flagellates and therefore more suitable for this species.

Acknowledgements. We thank N. H. Larsen for providing the algal cultures. This study was supported by Natural Research Council project no. 21-03-0449 to P.J.H.

\section{LITERATURE CITED}

Adolf JE, Stoecker DK, Harding LW (2006) The balance of autotrophy and heterotrophy during mixotrophic growth of Karlodinium micrum (Dinophyceae). J Plankton Res 28:737-751

Adolf JE, Krupatkina D, Bachvaroff T, Place AR (2007) Karlotoxin mediates grazing by Oxyrrhis marina on strains of Karlodinium veneficum. Harmful Algae 6:400-412

Berge T, Hansen PJ, Moestrup Ø (2008) Feeding mechanism, prey specificity and growth in light and dark of the plastidic dinoflagellate Karlodinium armiger. Aquat Microb Ecol 50:279-288

Bergholtz T, Daugbjerg N, Moestrup Ø (2006) On the identity of Karlodinium veneficum and description of Karlodinium armiger sp. nov. (Dinophyceae), based on light and electron microscopy, nuclear-encoded LSU rDNA, and pigment composition. J Phycol 42:170-193

Calado AJ, Moestrup Ø (1997) Feeding in Peridiniopsis berolinensis (Dinophyceae): new observations on tube feeding by an omnivorous, heterotrophic dinoflagellate. Phycologia 36:47-59

Calado AJ, Craveiro SC, Moestrup Ø (1998) Taxonomy and ultrastructure of a freshwater, heterotrophic Amphidinium (Dinophyceae) that feeds on unicellular protists. J Phycol 34:536-554

$>$ De Salas MF, Bolch CJS, Hallegreaff GM (2005) Karlodinium australe sp. nov. (Gymnodiniales, Dinophyceae), a new potentially ichthyotoxic unarmoured dinoflagellate from lagoonal habitats of south-eastern Australia. Phycologia 44:640-650

Deeds JR, Terlizzi DE, Adolf JE, Stoecker DK, Place AR (2002) Toxic activity from cultures of Karlodinium micrum (= Gyrodinium galatheanum) (Dinophyceae) $-\mathrm{a}$ dinoflagellate associated with fish mortalities in an estuarine aquaculture facility. Harmful Algae 1:169-189

Gaines T, Elbrächter M (1987) Heterotrophic nutrition. In: Taylor FJR (ed) The biology of dinoflagellates. Blackwell Scientific Publications, Oxford, p 224-268

Garcés E, Delgado M, Maso M, Camp J (1999) In situ growth rate and distribution of the ichthyotoxic dinoflagellate Gyrodinium corsicum Paulmier in a estuarine embayment (Alfacs Bay, NW Mediterranean Sea). J Plankton Res 21: 1977-1991

Guillard RRL, Hargraves PE (1993) Stichochrysis immobilis is a diatom, not a chrysophyte. Phycologia 32:234-236

Hansen PJ (1992) Prey size selection, feeding rates and growth dynamics of heterotrophic dinoflagellates with special emphasis on Gyrodinium spirale. Mar Biol 114: 327-334

Hansen PJ (1998) Phagotrophic mechanisms and prey selection in mixotrophic phytoflagellates. In: Anderson DM, Cembella AD, Hallegraeff GM (eds) Physiological ecology 
of harmful algal blooms. NATO ASI series G, ecological sciences, vol 41. Springer, New York, p 525-537

Hansen PJ, Calado AJ (1999) Phagotrophic mechanisms and prey selection in free-living dinoflagellates. J Eukaryot Microbiol 46:382-389

Hansen PJ, Bjørnsen PK, Hansen BW (1997) Zooplankton grazing and growth: scaling within the $2-2,000 \mu \mathrm{m}$ body size range. Limnol Oceanogr 42:687-704

> Hansen PJ, Miranda L, Azanza R (2004) Green Noctiluca scintillans: a dinoflagellate with its own greenhouse. Mar Ecol Prog Ser 275:79-87

Jacobson DM, Anderson DM (1986) Thecate heterotrophic dinoflagellates-feeding behavior and mechanisms. J Phycol 22:249-258

Jakobsen HH, Hansen PJ (1997) Prey size selection, grazing and growth response of the small heterotrophic dinoflagellate Gymnodinium sp. and the ciliate Balanion comatum - a comparative study. Mar Ecol Prog Ser 158: 75-86

Jakobsen HH, Hansen PJ, Larsen J (2000) Growth and grazing responses of two chloroplast-retaining dinoflagellates: effect of irradiance and prey species. Mar Ecol Prog Ser 201:121-128

Jakobsen HH, Everett LM, Strom SL (2006) Hydromechanical signaling between the ciliate Mesodinium pulex and motile protist prey. Aquat Microb Ecol 44:197-206

Jeong HJ, Du Yoo Y, Park JY, Song JY and others (2005a) Feeding by phototrophic red-tide dinoflagellates: five species newly revealed and six species previously known to be mixotrophic. Aquat Microb Ecol 40:133-150

Jeong HJ, Park JY, Nho JH, Park MO and others (2005b) Feeding by red-tide dinoflagellates on the cyanobacterium Synechococcus. Aquat Microb Ecol 41:131-143

Jones RI (1994) Mixotrophy in planktonic protists as a spectrum of nutritional strategies. Mar Microb Food Webs 48:87-96

Kiørboe T (1993) Turbulence, phytoplankton cell-size, and the structure of pelagic food webs. Adv Mar Biol 29:1-72

$>$ Li A, Stoecker DK, Adolf JE (1999) Feeding, pigmentation, photosynthesis and growth of the mixotrophic dinoflagellate Gyrodinium galatheanum. Aquat Microb Ecol 19:163-176

Li AS, Stoecker DK, Coats DW (2000a) Mixotrophy in Gyrodinium galatheanum (Dinophyceae): grazing responses to light intensity and inorganic nutrients. J Phycol 36:33-45

Li AS, Stoecker DK, Coats DW (2000b) Spatial and temporal aspects of Gyrodinium galatheanum in Chesapeake Bay: distribution and mixotrophy. J Plankton Res 22:2105-2124

Menden-Deuer S, Lessard EJ (2000) Carbon to volume relationships for dinoflagellates, diatoms, and other protist plankton. Limnol Oceanogr 45:569-579

Editorial responsibility: Klaus Jürgens, Rostock, Germany
Møgelhøj MK, Hansen PJ, Henriksen P, Lundholm N (2006) High $\mathrm{pH}$ and not allelopathy may be responsible for negative effects of Nodularia spumigena on other algae. Aquat Microb Ecol 43:43-54

Naustvoll LJ (2000a) Prey size spectra and food preferences in thecate heterotrophic dinoflagellates. Phycologia 39: $187-198$

Naustvoll LJ (2000b) Prey size spectra in naked heterotrophic dinoflagellates. Phycologia 39:448-455

Nygaard K, Tobiesen A (1993) Bacterivory in algae: a survival strategy during nutrient limitation. Limnol Oceanogr 38:273-279

Porter KG (1988) Phagotrophic phytoflagellates in microbial food webs. Hydrobiologia 159:89-97

Raven JA (1997) Phagotrophy in phototrophs. Limnol Oceanogr 42:198-205

Schmidt LE, Hansen PJ (2001) Allelopathy in the prymnesiophyte Chrysochromulina polylepis: effect of cell concentration, growth phase and pH. Mar Ecol Prog Ser 216: $67-81$

Skovgaard A (1996) Mixotrophy in Fragilidium subglobosum (Dinophyceae): growth and grazing responses as functions of light intensity. Mar Ecol Prog Ser 143:247-253

Skovgaard A (1998) Role of chloroplast retention in marine dinoflagellates. Aquat Microb Ecol 15:293-301

Skovgaard A (2000) A phagotrophically derivable growth factor in the plastidic dinoflagellate Gyrodinium resplendens (Dinophyceae). J Phycol 36:1069-1078

Smalley GW, Coats DW, Stoecker DK (2003) Feeding in the mixotrophic dinoflagellate Ceratium furca is influenced by intracellular nutrient concentrations. Mar Ecol Prog Ser 262:137-151

Smith M, Hansen PJ (2007) Interaction between Mesodinium rubrum and its prey: importance of prey concentration, irradiance and pH. Mar Ecol Prog Ser 338:61-70

Spero HJ (1985) Chemosensory capabilities in the phagotrophic dinoflagellate Gymnodium fungiforme. J Phycol 21:181-184

Stoecker DK (1998) Conceptual models of mixotrophy in planktonic protists and some ecological and evolutionary implications. Eur J Protistol 34:281-290

Stoecker DK, Li A, Coats DW, Gustafson DE, Nannen MK (1997) Mixotrophy in the dinoflagellate Prorocentrum minimum. Mar Ecol Prog Ser 152:1-12

Tillmann U (2004) Interactions between planktonic microalgae and protozoan grazers. J Eukaryot Microbiol 51: $156-168$

Turner JT, Tester PA (1997) Toxic marine phytoplankton, zooplankton grazers, and pelagic food webs. Limnol Oceanogr 42:1203-1214

Submitted: January 24, 2007; Accepted: November 20, 2007 Proofs received from author(s): March 18, 2008 